\title{
DOES FISCAL POLICY MATTER FOR BUSINESS R\&D INVESTMENT? PANEL DATA EVIDENCE FROM CENTRAL AND EASTERN EUROPE
}

\section{Shakhmuradyan, G.}

Gayane Shakhmuradyan / American University of Armenia, College of Business and Economics 40 Baghramyan Avenue, 0019, Yerevan, Armenia.Email: gayane_shakhmuradyan19@alumni.aua.am

\begin{abstract}
This paper examines the impact of fiscal policy on business investment in research and development (R\&D). Panel regression models - with independent variables for the total tax and contribution rate, government appropriations and outlays for $R \& D$, and the R\&D tax subsidy rate - are set up to examine cross-country differences in business investment in $R \& D$, with a set of control variables. The latter include, most notably, the number of full-time researchers, tertiary education attainment, the protection of intellectual property rights, governance, the long-term interest rate, and trade openness. The panel encompasses eleven countries of Central and Eastern Europe over ten years (2010-2019). The findings suggest that fiscal policy does not affect BERD, while trade openness, tertiary education attainment, and full-time researcher employment have a significant positive impact. These findings are consistent with some of the earlier studies on the effectiveness of fiscal policy in stimulating business investment, calling for greater allocation of public and private funds for R\&D professional development and training programs.

Implications for Central European audience: This paper used recent data for eleven Central and Eastern European countries. Therefore, the findings are directly applicable to these countries. As the paper used random-effects generalised least squares estimation for panel data, the findings can be generalised to other countries.
\end{abstract}

Keywords: corporate taxation; investment; research and development (R\&D); panel data; subsidies; tax incentives

JEL Classification: H25, O31, O34, O38

\section{Introduction}

Private investment in tangible and intangible assets, such as equipment and knowledge, is an important source of economic growth (Corrado et al., 2009; De Long \& Summers, 1991; Mankiw et al., 1992; Romer, 1986, 1990). Investment in research and development (R\&D) as an intangible asset is particularly notable as a source of growth, as it affects the rate of productivity-enhancing technological change, thus leading to improved welfare (Aghion \& 
Howitt, 1992; Arrow, 1962; Griliches, 1998; Grossman \& Helpman, 1990, 1991, 1994; Lichtenberg \& Siegel, 1991; Mokyr, 1992; Schumpeter, 1943).

To stimulate private investment in general and R\&D investment in particular, governments adopt a range of policies, including lowering the tax rate on corporate income and providing fiscal incentives for investment, e.g., tax credits and subsidies (Auerbach, 2018; Cummins et al., 1994; Griffith et al., 1995; Hassett \& Hubbard, 2002; Klemm, 2010; Leyden \& Link, 1993; Mansfield, 1982; Shah, 1995). However, fiscal policy is not the only factor affecting either tangible or intangible investment, as investment decisions also depend on such aspects of the investment climate as political stability and effective governance (Dawson, 1998; Edquist, 1997; R. E. Hall \& Jones, 1999; Klemm \& Van Parys, 2012; Van Parys \& James, 2010). More importantly, R\&D investment differs from other types of investment in two important respects: first, it is costlier to finance due to higher levels of uncertainty with regards to its returns, and second, its returns cannot be fully appropriated due to spillover effects (Arrow, 1962; Griffith et al., 1995; Griliches, 1992; B. H. Hall, 2002; B. H. Hall \& Lerner, 2010; B. Hall \& Van Reenen, 2000; Jones \& Williams, 1998, 2000).

This paper aims to contribute to the empirical literature on the effectiveness of fiscal incentives for investment by providing evidence on R\&D investment in Central and Eastern Europe. In the past two decades, panel data evidence of fixed and intangible investment has been documented for the Organisation for Economic Co-operation and Development (OECD) member states, as well as for countries in Africa and Latin America and the Caribbean (Bloom et al., 2002; Falk, 2006; Guellec \& Van Pottelsberghe De La Potterie, 2003; Klemm \& Van Parys, 2012; Thomson, 2017; Van Parys \& James, 2010; Wolff \& Reinthaler, 2008). However, to the best of our knowledge, there are no longitudinal studies on intangible investment in Central and Eastern Europe. Such a focus, in our view, would be especially effective in revealing the impact of fiscal policy on investment, as the crosssection is homogenous due to common history and comparable levels of economic development in the region.

The remainder of this paper is organised as follows. Section 1 reviews the literature on fiscal policy and private R\&D investment, focusing on longitudinal studies at the macroeconomic level. Section 2 describes the data and methods employed to empirically test the effects of taxes, government appropriations, and subsidies on business investment in R\&D. Sections 3 and 4 provide a discussion of the main findings of the current study and its implications for policy and management. A final section concludes.

\section{Literature review}

Cross-country empirical evidence on the effectiveness of fiscal policy in stimulating R\&D dates back to Mansfield (1986), whose data for the United States, Canada, and Sweden supported the hypothesis that tax credits, as well as other tax incentives, foster industrial R\&D. The reported rate of increase in investment is about 1-2 per cent, amounting to onethird of the foregone government revenue (Mansfield, 1986). Hall and Van Reenen (2000) surveyed the econometric evidence on the effectiveness of fiscal incentives for R\&D in several OECD countries, in particular the United States, Canada, Sweden, Australia, Japan, and France, concluding that a dollar in tax credit for R\&D stimulates a dollar of additional R\&D. Subsequent evidence that fiscal policy affects the level of business R\&D investment has been found, among others, by Bloom et al. (2002), Guellec and Van 
Pottelsberghe De La Potterie (2003), Falk (2006), Wolff and Reinthaler (2008), and Thomson (2017) (see Table 1 below for an overview of the data, methods, and main findings of these studies). Becker (2015) provides a systematic review of the literature on the effectiveness of public policies in increasing private R\&D investment, concluding that tax credits and subsidies, as well as university research, high-skilled human capital, and $R \& D$ cooperation are all found to have a positive impact on private $R \& D$ investment in $a$ range of empirical studies using different datasets and methodologies.

Table 1 | Overview of key contributions to the cross-country empirical study of fiscal policy and $R \& D$ investment

\begin{tabular}{|c|c|c|}
\hline Study & Data and Methods & Main findings \\
\hline $\begin{array}{l}\text { Bloom, Griffith, } \\
\text { and Van Reenen } \\
(2002)\end{array}$ & $\begin{array}{l}\text { Panel data of nine OECD } \\
\text { countries over } 19 \text { years } \\
\text { (1979-1997), } n=165 \\
\text { Ordinary least squares and } \\
\text { instrumental variables (IV) } \\
\text { regressions }\end{array}$ & $\begin{array}{l}\text { Tax incentives are effective in increasing } R \& D \\
\text { intensity, also when other factors are held constant. } \\
\text { Specifically, a } 10 \% \text { fall in the cost of } R \& D \text { stimulates } \\
\text { a } 1 \% \text { rise in the level of } R \& D \text { in the short run and a } \\
10 \% \text { rise in } R \& D \text { in the long run. }\end{array}$ \\
\hline $\begin{array}{l}\text { Guellec and Van } \\
\text { Pottelsberghe De } \\
\text { La Potterie } \\
(2003)\end{array}$ & $\begin{array}{l}\text { Panel data of } 17 \text { OECD } \\
\text { countries over } 14 \text { years } \\
\text { (1983-1996), } n=199 \\
\text { IV regressions }\end{array}$ & $\begin{array}{l}\text { Direct government funding and tax incentives both } \\
\text { have a positive impact on business R\&D. The } \\
\text { stimulating effect of government funding varies with } \\
\text { its generosity, increasing up to a threshold (about } \\
10 \% \text { of business } R \& D \text { ) and then decreasing. }\end{array}$ \\
\hline Falk (2006) & $\begin{array}{l}\text { Panel data of } 21 \text { OECD } \\
\text { countries over } 28 \text { years } \\
\text { (1975-2002), } n=99 \\
\text { Generalised method of } \\
\text { moments (GMM) estimator }\end{array}$ & $\begin{array}{l}\text { Tax incentives for R\&D and R\&D subsidies have a } \\
\text { significant positive impact on business } R \& D \\
\text { spending. }\end{array}$ \\
\hline $\begin{array}{lr}\text { Wolff and } \\
\text { Reinthaler (2008) }\end{array}$ & $\begin{array}{l}\text { Panel data of } 15 \text { OECD } \\
\text { countries over } 23 \text { years } \\
\text { (1981-2002), } n=255 \\
\text { IV regressions }\end{array}$ & $\begin{array}{l}\text { Subsidies are effective in generating additional } \\
\text { research expenditure. Expenditure for business } \\
\text { research increases by roughly } 20 \% \text { more than } \\
\text { employment. }\end{array}$ \\
\hline Thomson (2017) & $\begin{array}{l}\text { Panel data of } 26 \text { OECD } \\
\text { counties over } 20 \text { years } \\
\text { (1987-2006), } n=622 \\
\text { Fixed effects, first } \\
\text { difference, and GMM } \\
\text { estimators }\end{array}$ & $\begin{array}{l}\text { Reducing the tax price of R\&D by } 10 \% \text { induces an } \\
\text { additional } 5 \% \text { R\&D investment. }\end{array}$ \\
\hline
\end{tabular}

Note: The review is limited to peer-reviewed journal articles published between 2000 and 2020.

Source: author

\section{Methodology}

This paper takes the longitudinal (panel data) approach to assess the impact of fiscal policy on business R\&D investment, as this approach is the most appropriate for analysing crosssectoral differences over a given period of time (Wooldridge, 2010). The units of analysis are 11 Central and Eastern European (CEE) economies for which complete data are available for all the variables of interest (see Table 2 below for details on what variables are included in the analysis, how those are measured, and data sources; Table 3 provides an overview of the theoretical literature supporting the inclusion of these particular variables). The countries are Bulgaria, Croatia, the Czech Republic, Estonia, Hungary, Latvia, Lithuania, Poland, Romania, the Slovak Republic, and Slovenia. All are high-income 
countries, except Bulgaria (upper-middle-income), and all are members of the European Union (EU); at the time of writing (June 2021), five countries (Estonia, Latvia, Lithuania, Slovakia, and Slovenia) are members also of the Euro area. The years included in the analysis are 2010-2019, lending 110 observations per variable. There are no missing data, and thus, the panel is strongly balanced. Data were analysed with Stata 16 software: both the dataset and the command execution file are available upon request from the author.

Table 2 | Variables included in the analysis

\begin{tabular}{|c|c|c|c|}
\hline $\begin{array}{l}\text { Variable } \\
\text { (abbreviation) }\end{array}$ & Specification & Measurement & Data source \\
\hline $\begin{array}{l}\text { Business } \\
\text { enterprise } \\
\text { expenditure on } \\
R \& D \text { (BERD) }\end{array}$ & $\begin{array}{l}\text { Includes all expenditures for R\&D } \\
\text { performed within the business enterprise } \\
\text { sector on the national territory, regardless } \\
\text { of the source of funds. }\end{array}$ & $\%$ of GDP & $\begin{array}{l}\text { European } \\
\text { Commission } \\
(2021)\end{array}$ \\
\hline $\begin{array}{l}\text { Total tax and } \\
\text { contribution rate } \\
\text { (TTCR) }\end{array}$ & $\begin{array}{l}\text { Measures the amount of taxes and } \\
\text { mandatory contributions payable by } \\
\text { businesses after accounting for allowable } \\
\text { deductions and exemptions. }\end{array}$ & $\begin{array}{c}\text { \% of } \\
\text { commercial } \\
\text { profits }\end{array}$ & $\begin{array}{l}\text { World Bank } \\
\text { (2021) }\end{array}$ \\
\hline $\begin{array}{l}\text { Government } \\
\text { budget } \\
\text { appropriations } \\
\text { and outlays on } \\
R \& D \text { (GBAORD) }\end{array}$ & $\begin{array}{l}\text { Refers to national budget provisions (not } \\
\text { to actual expenditure) on government } \\
\text { support for R\&D. }\end{array}$ & $\begin{array}{l}\text { \% of general } \\
\text { government } \\
\text { expenditure }\end{array}$ & $\begin{array}{l}\text { European } \\
\text { Commission } \\
(2021)\end{array}$ \\
\hline $\begin{array}{l}\text { Implied tax } \\
\text { subsidy rate on } \\
R \& D \text { expenditures } \\
\text { (ITSR) }\end{array}$ & $\begin{array}{l}\text { The tax subsidy rate is defined as } 1 \\
\text { minus the B-index, a measure of the } \\
\text { before-tax income needed by a } \\
\text { 'representative' firm to break even on } \\
\text { USD } 1 \text { of R\&D outlays. The average is } \\
\text { taken for SMEs and large firms (profit } \\
\text { scenario). }\end{array}$ & 0 to 1 & OECD (2021) \\
\hline $\begin{array}{l}\text { Long-term interest } \\
\text { rate }(\mathrm{LTIR})\end{array}$ & $\begin{array}{l}\text { Refers to government bonds maturing in } \\
\text { ten years (EMU convergence criterion } \\
\text { bond yields). }\end{array}$ & $\%$ & $\begin{array}{l}\text { European } \\
\text { Commission } \\
(2021)\end{array}$ \\
\hline $\begin{array}{l}\text { GDP per capita } \\
\text { (GDPPC) }\end{array}$ & $\begin{array}{l}\text { Represents the value at current prices of } \\
\text { final goods and services produced within } \\
\text { a country, divided by the total population. }\end{array}$ & USD & $\begin{array}{l}\text { International } \\
\text { Monetary Fund } \\
(2021)\end{array}$ \\
\hline $\begin{array}{l}\text { Real GDP growth } \\
\text { rate (GRGDP) }\end{array}$ & $\begin{array}{l}\text { Represents the increase in the total value } \\
\text { at constant prices of final goods and } \\
\text { services produced within a country. }\end{array}$ & $\%$ change & $\begin{array}{l}\text { International } \\
\text { Monetary Fund } \\
(2021)\end{array}$ \\
\hline $\begin{array}{l}\text { Full-time } \\
\text { researchers (FTR) }\end{array}$ & $\begin{array}{l}\text { Researchers in the business enterprise } \\
\text { sector are professionals engaged in the } \\
\text { conception or creation of new knowledge, } \\
\text { products, processes, methods, and } \\
\text { systems, as well as in the management } \\
\text { of the projects concerned. }\end{array}$ & $\begin{array}{l}\text { Full-time } \\
\text { equivalent }\end{array}$ & $\begin{array}{l}\text { European } \\
\text { Commission } \\
(2021)\end{array}$ \\
\hline $\begin{array}{l}\text { Tertiary education } \\
\text { attainment (TE) }\end{array}$ & $\begin{array}{l}\text { Measures the proportion of the } \\
\text { population that has tertiary education, } \\
\text { i.e., International Standard Education } \\
\text { Classification (ISED) levels 5-8: } \\
\text { bachelor's, master's, and doctoral } \\
\text { degrees or equivalent. }\end{array}$ & $\begin{array}{l}\% \text { of population } \\
\text { ages } 15-64\end{array}$ & $\begin{array}{l}\text { European } \\
\text { Commission } \\
\text { (2021) }\end{array}$ \\
\hline
\end{tabular}




\begin{tabular}{llll}
\hline $\begin{array}{l}\text { Governance } \\
\text { (GOV) }\end{array}$ & $\begin{array}{l}\text { Governance consists of the traditions and } \\
\text { institutions by which authority in a country } \\
\text { is exercised. It measures voice and } \\
\text { accountability, political stability, } \\
\text { government effectiveness, regulatory } \\
\text { quality, rule of law, and control of } \\
\text { corruption in a country. }\end{array}$ & -0.25 to 0.25 & $\begin{array}{l}\text { World Bank } \\
(2020)\end{array}$ \\
& $\begin{array}{l}\text { Measures the protection of intellectual } \\
\text { property rights in a country. }\end{array}$ & 0 to 10 & $\begin{array}{l}\text { Property Rights } \\
\text { Alliance (2020) }\end{array}$ \\
$\begin{array}{l}\text { Intellectual } \\
\text { property rights } \\
\text { (IPR) }\end{array}$ & $\begin{array}{l}\text { Trade is the sum of exports and imports } \\
\text { of goods and services. }\end{array}$ & \% of GDP & $\begin{array}{l}\text { World Bank } \\
\text { (2021) }\end{array}$ \\
\hline Trade (TRADE) & & & \\
\hline
\end{tabular}

Notes: Research and development (R\&D) is defined as "creative work undertaken on a systematic basis in order to increase the stock of knowledge, including knowledge of man, culture and society, and the use of this stock of knowledge to devise new applications" (European Commission, 2021). Time frequency for the measurement of all variables is annual (calendar year).

Source: author

Three partial models that this study aims to estimate are as follows:

$$
\begin{gathered}
B E R D_{i t}=\beta_{0}+\beta_{1} \text { TTCR }_{i t}+u_{i t} \\
B E R D_{i t}=\beta_{0}+\beta_{1} \text { GBAORD }_{i t}+u_{i t} \\
B E R D_{i t}=\beta_{0}+\beta_{1} \text { ITSR }_{i t}+u_{i t}
\end{gathered}
$$

Three fuller models have the following forms:

$$
\begin{aligned}
& B E R D_{i t}=\beta_{0}+\beta_{1} T T C R_{i t}+\beta_{2} G B A O R D_{i t}+\beta_{3} I T S R_{i t}+u_{i t} \\
& B E R D_{i t}=\beta_{0}+\beta_{1} T_{T C R}+\beta_{2} G B A O R D_{i t}+\beta_{3} I T S R_{i t}+\beta_{4} L T I R_{i t}+\beta_{5} F_{T R}+\beta_{6} T E_{i t}+ \\
& \beta_{7} G O V_{i t}+\beta_{8} I P R_{i t}+u_{i t} \\
& B E R D_{i t}=\beta_{0}+\beta_{1} T_{T C R}+\beta_{2} \text { GBAORD }_{i t}+\beta_{3} \text { ITSR }_{i t}+\beta_{4} \text { LTIR }_{i t}+\beta_{5} F T R_{i t}+\beta_{6} T E_{i t}+ \\
& \beta_{7} G O V_{i t}+\beta_{8} I P R_{i t}+\beta_{9} T R A D E_{i t}+\beta_{10} G D P P C_{i t}+\beta_{11} G R G D P_{i t}+u_{i t}
\end{aligned}
$$

The first three specifications would allow revealing the impact of taxation and government expenditure on $R \& D$ investment irrespective of other factors that have been found in prior literature as affecting R\&D investment. The fourth model examines the impact of the three fiscal policy variables jointly. The fifth model adds to fiscal policy some variables for the general investment environment, namely the long-term interest rate, the number of full-time researchers, tertiary education attainment rate, the governance score, and the protection of intellectual property rights. The final model incorporates trade openness and the level of economic growth and development in a country, as measured by the GDP growth rate and GDP per capita. It is expected that in both the partial and full models, the total tax and contribution rate would have a negative impact on business R\&D investment, while government budget appropriations and the subsidy rate would have a positive impact. 
Table 3 | Theoretical justifications for the inclusion of independent variables

\begin{tabular}{|c|c|c|c|}
\hline $\begin{array}{l}\text { Variable } \\
\text { (abbreviation) }\end{array}$ & Expected Sign & Theory & References \\
\hline $\begin{array}{l}\text { Total tax and } \\
\text { contribution rate } \\
\text { (TTCR) }\end{array}$ & - & \multirow{3}{*}{$\begin{array}{l}\text { Tax policy is highly effective in } \\
\text { changing the level and timing of } \\
\text { business investment. Changes in } \\
\text { tax policy change the cost of capital, } \\
\text { thus resulting in business } \\
\text { investment or disinvestment. }\end{array}$} & \multirow{3}{*}{$\begin{array}{l}\text { Jorgenson (1963), } \\
\text { Hall and Jorgenson } \\
(1967,1969), \\
\text { King (1974), } \\
\text { Auerbach (1979), } \\
\text { Hassett and Hubbard } \\
(2002)\end{array}$} \\
\hline $\begin{array}{l}\text { Government } \\
\text { budget } \\
\text { appropriations and } \\
\text { outlays on R\&D } \\
\text { (GBAORD) }\end{array}$ & + & & \\
\hline $\begin{array}{l}\text { Implied tax } \\
\text { subsidy rate on } \\
R \& D \text { expenditures } \\
\text { (ITSR) }\end{array}$ & + & & \\
\hline $\begin{array}{l}\text { Long-term interest } \\
\text { rate }(\mathrm{LTIR})\end{array}$ & - & $\begin{array}{l}\text { A higher rate of interest decreases } \\
\text { the marginal benefit to research by } \\
\text { reducing the present value of } \\
\text { monopoly profits. }\end{array}$ & $\begin{array}{l}\text { Aghion and Howitt } \\
\text { (1992) }\end{array}$ \\
\hline $\begin{array}{l}\text { GDP per capita } \\
\text { (GDPPC) }\end{array}$ & + & $\begin{array}{l}\text { Rich countries invest more in } R \& D \\
\text { than poor countries. }\end{array}$ & Falk (2006) \\
\hline $\begin{array}{l}\text { Real GDP growth } \\
\text { rate (GRGDP) }\end{array}$ & + & $\begin{array}{l}\text { Rising GDP implies that businesses } \\
\text { see rising profits and increased } \\
\text { sales and cash flow, thus making } \\
\text { greater use of the existing capacity. }\end{array}$ & Wang (2010) \\
\hline $\begin{array}{l}\text { Full-time } \\
\text { researchers (FTR) }\end{array}$ & + & $\begin{array}{l}\text { A greater endowment of skilled } \\
\text { labour increases the marginal } \\
\text { benefit of research and reduces the } \\
\text { marginal cost of research. }\end{array}$ & $\begin{array}{l}\text { Aghion and Howitt } \\
\text { (1992) }\end{array}$ \\
\hline $\begin{array}{l}\text { Tertiary education } \\
\text { attainment (TE) }\end{array}$ & + & $\begin{array}{l}\text { Human capital stock is } \\
\text { an important determinant } \\
\text { of national R\&D efforts and } \\
\text { innovative capacity. }\end{array}$ & Wang (2010) \\
\hline $\begin{array}{l}\text { Governance } \\
\text { (GOV) }\end{array}$ & + & $\begin{array}{l}\text { Investment climate variables that } \\
\text { are under the control of the } \\
\text { government are important in } \\
\text { attracting and sustaining private } \\
\text { investment. }\end{array}$ & $\begin{array}{l}\text { Edquist (1997), } \\
\text { Dawson (1998), } \\
\text { Hall and Jones } \\
\text { (1999), } \\
\text { Van Parys and } \\
\text { James (2010) }\end{array}$ \\
\hline $\begin{array}{l}\text { Intellectual } \\
\text { property rights } \\
\text { protection (IPR) }\end{array}$ & + & $\begin{array}{l}\text { Patent laws and other protection } \\
\text { measures related to intellectual } \\
\text { property reduce the uncertainty that } \\
\text { surrounds the appropriation of R\&D } \\
\text { investment results. }\end{array}$ & Varsakelis (2001) \\
\hline Trade (TRADE) & + & $\begin{array}{l}\text { The more open the economy is the } \\
\text { higher the marginal productivity of } \\
\text { the stock of knowledge and the } \\
\text { higher the desire for new investment } \\
\text { in R\&D. }\end{array}$ & $\begin{array}{l}\text { Grossman and } \\
\text { Helpman (1991), } \\
\text { Varsakelis (2001) }\end{array}$ \\
\hline
\end{tabular}

Source: author 


\section{Findings}

Table 4 below provides descriptive statistics of the twelve variables included in the study. As can be observed, the mean rate of BERD as a per cent of GDP is 0.62: the minimum is 0.11 (Latvia, 2016), while the maximum is 1.96 (Slovenia, 2013). The mean total tax and contribution rate (\% of profits) is 39.4 , with a minimum of 18.4 (Croatia, 2014) and a maximum of 66.6 (Estonia, 2012). The average rate of government budget appropriations and outlays for R\&D (\% of general government expenditure) is 0.99 , with a minimum of 0.35 (Latvia, 2010) and a maximum of 2.12 (Estonia, 2013). The mean implied tax subsidy rate on $R \& D$ expenditures ( 1 minus the $B$-index) is 0.12 (minimum of -0.01 in Slovakia, 2010-2014; maximum of 0.41 in Slovakia, 2019).

Among the non-tax factors affecting investment, the long-term interest rate has a mean of 3.25 (minimum of 0.25 in Slovakia, 2019, and maximum of 10.34 in Latvia, 2010). The governance score has a mean of 0.69, with a minimum of 0.13 (Bulgaria, 2013-2016) and a maximum of 1.24 (Estonia, 2017-2019). The mean annual GDP growth rate is 2.7, with a minimum of -4.4 in Latvia 2010 and a maximum of 7.4 in Estonia 2011. Tertiary education attainment has a mean of 23.3, with a minimum of 11.9 (Romania, 2010) and a maximum of 37.9 (Lithuania, 2019). The intellectual property rights score has a mean of 5.9, with a minimum of 4.8 (Bulgaria, 2017) and a maximum of 7.2 (Estonia, 2017-2019). Trade as a per cent of GDP has a mean of 131.6; the minimum value (71) is observed in Romania in 2010, while the maximum (191) is observed in Slovakia in 2018.

Table 4 | Descriptive statistics

\begin{tabular}{|c|c|c|c|c|c|c|}
\hline Variable & & Mean & Std. dev. & Min. & Max. & Obs. \\
\hline \multirow[t]{3}{*}{ BERD } & overall & 0.62 & 0.45 & 0.11 & 1.96 & $\mathrm{~N}=110$ \\
\hline & between & & 0.44 & 0.17 & 1.64 & $\mathrm{n}=11$ \\
\hline & within & & 0.15 & 0.32 & 1.24 & $\mathrm{~T}=10$ \\
\hline \multirow{3}{*}{ TTCR } & overall & 39.37 & 9.78 & 18.4 & 66.6 & $\mathrm{~N}=110$ \\
\hline & between & & 9.68 & 20.42 & 51.43 & $\mathrm{n}=11$ \\
\hline & within & & 3.11 & 19.45 & 54.54 & $\mathrm{~T}=10$ \\
\hline \multirow[t]{3}{*}{ GBAORD } & overall & 0.99 & 0.43 & 0.35 & 2.12 & $\mathrm{~N}=110$ \\
\hline & between & & 0.43 & 0.46 & 1.81 & $n=11$ \\
\hline & within & & 0.12 & 0.71 & 1.56 & $\mathrm{~T}=10$ \\
\hline \multirow[t]{3}{*}{ ITSR } & overall & 0.12 & 0.12 & -0.01 & 0.41 & $\mathrm{~N}=110$ \\
\hline & between & & 0.10 & 0 & 0.31 & $\mathrm{n}=11$ \\
\hline & within & & 0.07 & -0.01 & 0.43 & $\mathrm{~T}=10$ \\
\hline \multirow[t]{3}{*}{ LTIR } & overall & 3.25 & 2.11 & 0.25 & 10.34 & $\mathrm{~N}=110$ \\
\hline & between & & 1.10 & 1.96 & 5.12 & $\mathrm{n}=11$ \\
\hline & within & & 1.83 & 0.44 & 10.57 & $\mathrm{~T}=10$ \\
\hline \multirow[t]{3}{*}{$\log G D P P C$} & overall & 9.61 & 0.32 & 8.81 & 10.17 & $\mathrm{~N}=110$ \\
\hline & between & & 0.32 & 8.98 & 10.07 & $n=11$ \\
\hline & within & & 0.11 & 9.34 & 9.87 & $\mathrm{~T}=10$ \\
\hline \multirow[t]{3}{*}{ GRGDP } & overall & 2.74 & 2.10 & -4.4 & 7.4 & $\mathrm{~N}=110$ \\
\hline & between & & 0.80 & 1.04 & 3.74 & $n=11$ \\
\hline & within & & 1.96 & -4.26 & 6.94 & $\mathrm{~T}=10$ \\
\hline \multirow[t]{3}{*}{$\log$ FTR } & overall & 8.30 & 1.18 & 6.32 & 10.97 & $\mathrm{~N}=110$ \\
\hline & between & & 1.18 & 6.46 & 10.20 & $\mathrm{n}=11$ \\
\hline & within & & 1.33 & 7.36 & 9.08 & $\mathrm{~T}=10$ \\
\hline \multirow{3}{*}{$T E$} & overall & 23.26 & 6.18 & 11.9 & 37.9 & $\mathrm{~N}=110$ \\
\hline & between & & 5.92 & 14.32 & 33.28 & $\mathrm{n}=11$ \\
\hline & within & & 2.46 & 17.98 & 29.09 & $\mathrm{~T}=10$ \\
\hline GOV & overall & 0.69 & 0.31 & 0.13 & 1.24 & $\mathrm{~N}=110$ \\
\hline
\end{tabular}




\begin{tabular}{|c|c|c|c|c|c|c|}
\hline & $\begin{array}{l}\text { between } \\
\text { within }\end{array}$ & & $\begin{array}{l}0.31 \\
0.08\end{array}$ & $\begin{array}{l}0.19 \\
0.53\end{array}$ & $\begin{array}{l}1.17 \\
0.87\end{array}$ & $\begin{array}{l}\mathrm{n}=11 \\
\mathrm{~T}=10\end{array}$ \\
\hline \multirow[t]{2}{*}{$I P R$} & overall & 5.91 & 0.57 & 4.8 & 7.2 & $\mathrm{~N}=110$ \\
\hline & $\begin{array}{l}\text { between } \\
\text { within }\end{array}$ & & $\begin{array}{l}0.54 \\
0.24\end{array}$ & $\begin{array}{l}5.06 \\
5.13 \\
\end{array}$ & $\begin{array}{l}6.78 \\
6.51 \\
\end{array}$ & $\begin{array}{l}\mathrm{n}=11 \\
\mathrm{~T}=10\end{array}$ \\
\hline \multirow[t]{2}{*}{ TRADE } & overall & 131.62 & 31.38 & 71 & 191 & $\mathrm{~N}=110$ \\
\hline & $\begin{array}{l}\text { between } \\
\text { within }\end{array}$ & & $\begin{array}{l}31.69 \\
7.97 \\
\end{array}$ & $\begin{array}{l}82.3 \\
107.92 \\
\end{array}$ & $\begin{array}{l}178.7 \\
147.02\end{array}$ & $\begin{array}{l}\mathrm{n}=11 \\
\mathrm{~T}=10\end{array}$ \\
\hline
\end{tabular}

Source: author

Line plots of the variables over the ten years (see Figures 1 and 2 below) do not reveal a covariance between government budget appropriations and BERD; implied tax subsidy rates are generally very low (equal to zero for some countries: Bulgaria, Estonia, Croatia, Romania for the whole or most of the observed period) and do not seem to covary with BERD. BERD does not move along with the GDP growth rate and the long-term interest rate either but seems to be associated with the governance score. Table 5 provides a matrix of the pairwise correlations between the dependent variable and the independent variables, as well as among the independent variables. It can be observed that BERD is significantly positively corrected with GBAORD $(r=0.31, p \leq 0.10)$, GDPPC $(r=0.54, p \leq 0.01)$, FTR $(r=0.31, p \leq 0.05)$, GOV $(r=0.40, p \leq 0.05)$, IPR $(r=0.32, p \leq 0.05)$, and TRADE $(r=0.42$, $p \leq 0.05)$. There is no statistically significant relationship between either BERD and TTCR or BERD and ITSR. Among the independent variables, there are positive correlations between, most notably, TTCR and IPR $(r=0.74, p \leq 0.01)$, GOV and GDPPC ( $r=0.83$, $p \leq 0.01)$, and GOV and IPR ( $r=0.72, p \leq 0.01)$.

Figure 1 | Business enterprise expenditure on R\&D, government budget appropriations and outlays for R\&D and implied tax subsidy rates in CEE countries, 2010-2019

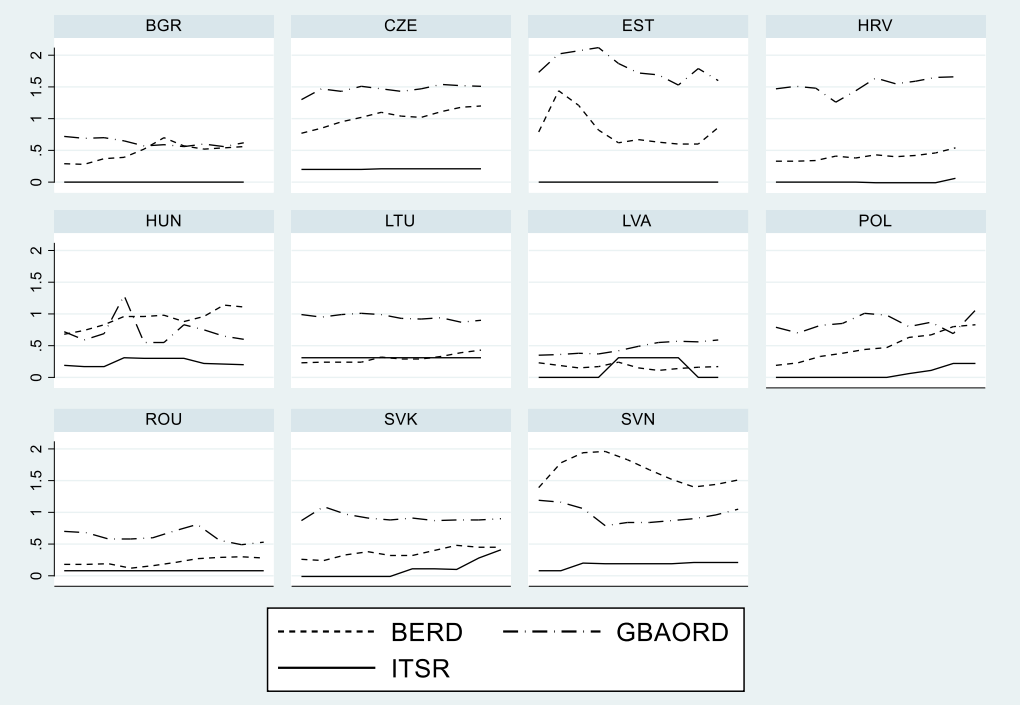

Note: Standard three-letter country codes are applied, as follows: BGR-Bulgaria, CZE-Czech Republic, EST-Estonia, HRV-Croatia, HUN-Hungary, LTU-Lithuania, LVA-Latvia, POL-Poland, ROU-Romania, SVK-Slovak Republic, SVN-Slovenia.

Source: author 
Abbreviations: BERD-business expenditure on research and development, GBAORD-government budget appropriations and outlays for R\&D, ITSR-implied tax subsidy rate.

Figure 2 | Business enterprise expenditure on R\&D, GDP growth rates, long-term interest rates, and governance scores in CEE countries, 2010-2019

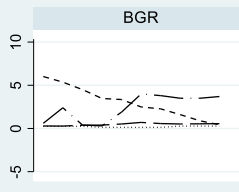

HUN

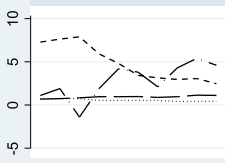

ROU
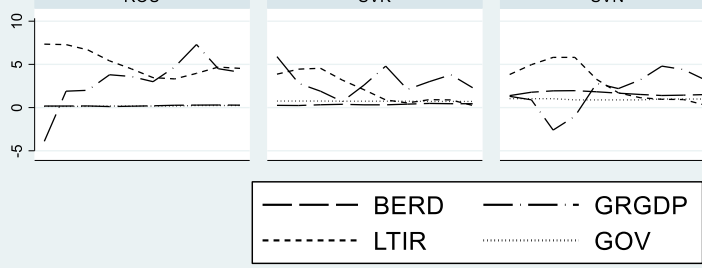

EST

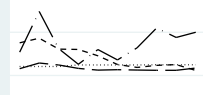

LVA

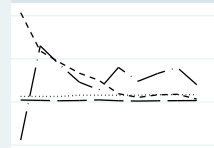

SVN

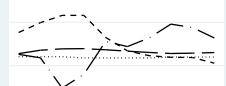

GRGDP

Source: authors

Note: Standard three-letter country codes are applied, as follows: BGR-Bulgaria, CZE-Czech Republic, EST-Estonia, HRV-Croatia, HUN-Hungary, LTU-Lithuania, LVA-Latvia, POL-Poland, ROU-Romania, SVK-Slovak Republic, SVN-Slovenia.

Abbreviations: BERD-business expenditure on research and development, GRGDP-growth of GDP, LTIR-long-term interest rate, GOV-governance. 
Table 5 | Pairwise correlations

\begin{tabular}{|c|c|c|c|c|c|c|c|c|c|c|c|c|}
\hline & $\begin{array}{l}\infty \\
\text { M } \\
0\end{array}$ & $\begin{array}{l}\text { 검 } \\
\text { Dౌ }\end{array}$ & 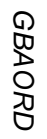 & जे & $\stackrel{5}{-1}$ & $\begin{array}{l}0 \\
0 \\
0 \\
0\end{array}$ & $\begin{array}{l}D \\
D \\
D \\
0\end{array}$ & $\frac{7}{D}$ & -17 & ९̊ & $\bar{D}$ & $\underset{\substack{D \\
0}}{-1}$ \\
\hline $\begin{array}{l}\infty \\
\text { m } \\
0 \\
0\end{array}$ & $\overrightarrow{8}$ & & & & & & & & & & & \\
\hline $\begin{array}{l}\text { 국 } \\
\text { D }\end{array}$ & $\stackrel{\circ}{9}$ & $\dot{8}$ & & & & & & & & & & \\
\hline ग & $\underset{*}{\stackrel{O}{\omega}}$ & $\stackrel{\circ}{\vec{v}}$ & $\overrightarrow{8}$ & & & & & & & & & \\
\hline $\overrightarrow{\bar{D}}$ & $\stackrel{\circ}{\text { N }}$ & $\stackrel{\circ}{\text { N }}$ & 官 & $\overrightarrow{8}$ & & & & & & & & \\
\hline$\stackrel{-1}{>}$ & $\stackrel{\dot{D}}{\vec{D}}$ & $\begin{array}{l}\dot{0} \\
\dot{8}\end{array}$ & $\begin{array}{l}\dot{1} \\
\text { N }\end{array}$ & $\begin{array}{l}\dot{0} \\
\text { N }\end{array}$ & $\overrightarrow{8}$ & & & & & & & \\
\hline $\begin{array}{l}0 \\
0 \\
0 \\
0\end{array}$ & $\underset{\substack{y \\
* \\
*}}{0}$ & $\underset{*}{\stackrel{\circ}{\omega}}$ & $\begin{array}{l}\stackrel{0}{ } \\
\dot{0} \\
* \\
*\end{array}$ & 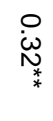 & $\begin{array}{l}\dot{1} \\
\dot{0} \\
\dot{0} \\
*\end{array}$ & $\dot{8}$ & & & & & & \\
\hline $\begin{array}{l}\text { D } \\
\text { D } \\
\stackrel{D}{0}\end{array}$ & $\begin{array}{l}\dot{0} \\
\dot{\omega}\end{array}$ & 으N & $\begin{array}{l}\dot{0} \\
\text { 우 }\end{array}$ & $\stackrel{\circ}{\vec{\exists}}$ & $\begin{array}{l}\dot{1} \\
\text { cf } \\
\text { ज } \\
* \\
*\end{array}$ & $\stackrel{\circ}{\overrightarrow{0}}$ & $\dot{8}$ & & & & & \\
\hline$\frac{7}{7}$ & $\underset{\stackrel{\circ}{+}}{\stackrel{*}{*}}$ & $\stackrel{\circ}{\text { N }}$ & ’் & $\stackrel{\circ}{i}$ & $\begin{array}{l}\dot{0} \\
\text { Oे }\end{array}$ & $\begin{array}{l}\circ \\
\text { 움 }\end{array}$ & $\stackrel{\circ}{\vec{D}}$ & $\overrightarrow{\dot{\circ}}$ & & & & \\
\hline in & $\stackrel{\circ}{\vec{\omega}}$ & $\stackrel{\circ}{\vec{A}}$ & $\stackrel{\circ}{\overrightarrow{0}}$ & $\begin{array}{l}\circ \\
\text { N }\end{array}$ & $\begin{array}{l}\dot{1} \\
\text { or } \\
+ \\
* \\
*\end{array}$ & 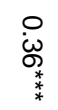 & ○् & $\begin{array}{l}\dot{0} \\
\text { N }\end{array}$ & $\overrightarrow{8}$ & & & \\
\hline$\stackrel{\text { O̊ }}{\text { O }}$ & \begin{tabular}{l}
$\stackrel{0}{0}$ \\
$\dot{+}$ \\
\multirow{*}{*}{}
\end{tabular} & \begin{tabular}{l}
$\stackrel{\circ}{+}$ \\
$\stackrel{*}{+}$ \\
\multirow{*}{*}{}
\end{tabular} & 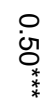 & $\begin{array}{l}\stackrel{O}{N} \\
\stackrel{N}{n}\end{array}$ & $\underset{⿱ 亠}{\dot{v}}$ & $\begin{array}{l}. \\
\stackrel{\infty}{\infty} \\
\omega_{*}^{*} \\
* \\
*\end{array}$ & $\begin{array}{l}\circ \\
\dot{8}\end{array}$ & 응 & $\underset{\stackrel{0}{\circ}}{\stackrel{0}{*}}$ & $\dot{8}$ & & \\
\hline $\bar{D}$ & 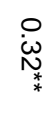 & 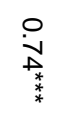 & $\begin{array}{l}0 \\
\stackrel{0}{+} \\
\stackrel{*}{*} \\
*\end{array}$ & $\begin{array}{l}\circ \\
\text { N }\end{array}$ & $\begin{array}{l}\circ \\
\text { N }\end{array}$ & ○ & $\stackrel{\circ}{\vec{\theta}}$ & 웅 & $\begin{array}{c}0 \\
\dot{\omega} \\
\underset{*}{*} \\
* \\
*\end{array}$ & $\underset{\substack{+\multirow{N}{*}{*}\\
*}}{*}$ & $\dot{8}$ & \\
\hline 永 & 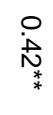 & 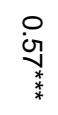 & $\stackrel{\circ}{\vec{v}}$ & 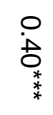 & $\begin{array}{l}\dot{0} \\
\dot{\infty} \\
\stackrel{*}{*}\end{array}$ & $\begin{array}{l}\circ \\
\text { ㅇ } \\
+ \\
* \\
*\end{array}$ & $\stackrel{\circ}{\vec{V}}$ & 응 & \begin{tabular}{l}
0 \\
$\dot{\omega}$ \\
\multirow{*}{*}{}
\end{tabular} & 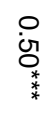 & 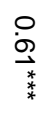 & $\overrightarrow{\dot{8}}$ \\
\hline
\end{tabular}

Source: author

Notes: ${ }^{*} p \leq 0.10,{ }^{* *} p \leq 0.05,{ }^{* * *} p \leq 0.01$. Bonferroni-adjusted significance levels are reported. 
Fixed-effects and random-effects linear generalised least squares (GLS) regression models were estimated to establish causal relations between BERD and the independent variables of interest. The random-effects GLS estimates were more efficient and are reported below; fixed-effects regression results are provided in the appendix. The results (see Table 6) suggest that neither taxes nor government appropriations and subsidies have an impact on business $R \& D$ while controlling for other factors. In the partial models (1-3) neither of the three fiscal policy variables (TTCR, GBAORD, and ITSR) is significant. The coefficients of TTCR and ITSR are not substantially different from zero, while test statistics are not significant also in the two fuller models (4 and 6). The GBAORD statistic is significant at the $5 \%$-level in the fifth model, suggesting that a $1 \%$ increase in government budget appropriations and outlays for R\&D could be associated with a $21 \%$ increase in BERD. However, the fifth model has low explanatory power for the between-country variance in $\operatorname{BERD}\left(R^{2}=0.08\right)$.

The number of full-time equivalent researchers is the most significant factor affecting BERD in the last two specifications of the model. In the sixth specification, which explains $78 \%$ of the cross-country variance in BERD, the FTR statistic is $0.25(p<0.01)$, suggesting that one per cent increase in FTR is associated with a $25 \%$ increase in BERD while controlling for a number of other factors that may affect BERD. The long-term interest rate, tertiary education attainment, intellectual property rights, trade, and GDP per capita variables are also significant in the sixth model, suggesting that ceteris paribus, higher long-term interest rate, higher rate of tertiary education attainment, greater trade openness, and higher GDP per capita are associated with an increase in BERD, while improvement in intellectual property rights protection is associated with a decrease in BERD. 
Table 6 | Random-effects GLS regression results

\begin{tabular}{|c|c|c|c|c|c|c|}
\hline & (1) & (2) & (3) & (4) & (5) & (6) \\
\hline \multirow[t]{2}{*}{ TTCR } & 0.00 & & & 0.00 & 0.00 & -0.01 \\
\hline & $(0.01)$ & & & $(0.01)$ & $(0.01)$ & $(0.01)$ \\
\hline \multirow[t]{2}{*}{ GBAORD } & & 0.19 & & 0.16 & $0.21^{* *}$ & 0.24 \\
\hline & & $(0.19)$ & & $(0.13)$ & $(0.11)$ & $(0.16)$ \\
\hline \multirow[t]{2}{*}{ ITSR } & & & 0.49 & 0.48 & 0.02 & -0.35 \\
\hline & & & $(0.34)$ & $(0.35)$ & $(0.16)$ & $(0.54)$ \\
\hline \multirow[t]{2}{*}{ LTIR } & & & & & $0.04^{*}$ & $0.07^{\star *}$ \\
\hline & & & & & $(0.02)$ & (0.03) \\
\hline \multirow[t]{2}{*}{ Log FTR } & & & & & $0.22^{\star \star \star}$ & $0.25^{\star \star \star}$ \\
\hline & & & & & $(0.05)$ & $(0.06)$ \\
\hline \multirow[t]{2}{*}{$T E$} & & & & & $0.03^{\star \star *}$ & $0.03^{\star *}$ \\
\hline & & & & & $(0.01)$ & $(0.01)$ \\
\hline \multirow[t]{2}{*}{ GOV } & & & & & $-0.58^{\star \star}$ & -0.26 \\
\hline & & & & & $(0.29)$ & (0.32) \\
\hline \multirow[t]{2}{*}{ IPR } & & & & & -0.01 & $-0.29^{*}$ \\
\hline & & & & & $(0.04)$ & $(0.16)$ \\
\hline \multirow[t]{2}{*}{ TRADE } & & & & & & $0.01^{* \star *}$ \\
\hline & & & & & & $(0.00)$ \\
\hline \multirow[t]{2}{*}{ GRGDP } & & & & & & -0.02 \\
\hline & & & & & & $(0.02)$ \\
\hline \multirow[t]{2}{*}{ Log GDPPC } & & & & & & $0.93^{\star *}$ \\
\hline & & & & & & $(0.42)$ \\
\hline \multirow[t]{2}{*}{ Constant } & 0.44 & $0.43^{*}$ & $0.56^{* * *}$ & 0.29 & $-1.81^{* \star *}$ & $-9.98^{\star \star *}$ \\
\hline & $(0.50)$ & $(0.24)$ & $(0.13)$ & $(0.53)$ & $(0.48)$ & (3.47) \\
\hline$\sigma u$ & 0.46 & 0.44 & 0.45 & 0.46 & 0.56 & 0.00 \\
\hline$\sigma e$ & 0.15 & 0.15 & 0.15 & 0.15 & 0.11 & 0.11 \\
\hline $\begin{array}{l}\rho \text { (fraction of } \\
\text { variance due to } u \\
\text { i) }\end{array}$ & 0.90 & 0.89 & 0.90 & 0.90 & 0.96 & 0.00 \\
\hline \multirow{4}{*}{$\begin{array}{r}\text { within } \\
\text { between } \\
\text { overall } \\
\text { Observations }\end{array}$} & 0.01 & 0.02 & 0.05 & 0.08 & 0.50 & 0.30 \\
\hline & 0.00 & 0.11 & 0.06 & 0.17 & 0.05 & 0.78 \\
\hline & 0.00 & 0.10 & 0.05 & 0.15 & 0.08 & 0.70 \\
\hline & 110 & 110 & 110 & 110 & 110 & 110 \\
\hline Groups & 11 & 11 & 11 & 11 & 11 & 11 \\
\hline
\end{tabular}

Notes: Dependent variable: BERD. ${ }^{*} p \leq 0.10,{ }^{* *} p \leq 0.05,{ }^{* *} p \leq 0.01$. Clustered robust standard errors in parentheses.

\section{Discussion}

The results obtained in this paper are consistent with earlier longitudinal studies on the impact of tax incentives on fixed investment (Klemm \& Van Parys, 2012; Van Parys \& James, 2010), suggesting that tax policy is not effective in stimulating additional investment in the private sector. The results contradict evidence reported by several researchers of R\&D investment (Bloom et al., 2002; Falk, 2006; Guellec \& Van Pottelsberghe De La Potterie, 2003; Thomson, 2017; Wolff \& Reinthaler, 2008), who find that government expenditure and tax incentives have a positive impact on private investment in R\&D. This may be due to the methodological limitations of the paper, as advanced approaches to panel data analysis, such as instrumental variables or generalised method of moments 
estimators, were not utilised. Nevertheless, the random-effects GLS estimation was made more robust with autocorrelation- and heteroscedasticity-consistent standard errors.

The most important finding of the current paper, i.e., that the number of full-time researchers has a significant positive impact on BERD, is supported by theory and prior empirical evidence. In their seminal contribution, Aghion and Howitt (1992) stated, inter alia, that 'a greater endowment of skilled labour increases the marginal benefit of research and reduces the marginal cost of research'. Goolsbee (1998) found that as most R\&D spending at the firm level is salary payments for R\&D workers, a significant fraction of the increased government spending on $R \& D$ goes directly into higher wages; in that sense, $R \& D$ policy is 'less about increasing innovation and more about rewarding the human capital of scientists' (Goolsbee, 1998, p. 298). Wang (2010) found the proportion of scientific researchers in the total population to be a robust determinant of $R \& D$ intensity.

The finding of this paper that trade openness positively affects $R \& D$ investment is consistent with the Grossman and Helpman (1991) model of innovation in a global economy; Coe and Helpman (1995) have provided empirical evidence on the significance of international R\&D spillovers. The finding that tertiary education attainment has a positive and significant impact on BERD is consistent with Wang (2010), who found tertiary education to be a robust determinant of $R \& D$ intensity using extreme bounds analysis for data of 26 OECD countries. In contrast to Varsakelis (2001), effective governance and the protection of intellectual property rights are not found to have a significant positive impact on R\&D. In contrast to Falk (2006), GDP per capita is found to have a positive impact, in line with the theory that richer nations spend more on $R \& D$.

The main implication of the findings of this paper, in line with Goolsbee (1998), is that it can cost less to the government to subsidise business investment in training and development programs for R\&D professionals or fund science, technology, and engineering departments at universities than to reduce the corporate income tax rate. The second implication, in line with Grossman and Helpman (1991), is that trade policy should be geared towards greater openness, as the import and export of goods and services facilitate the exchange of knowledge and its application in business. The implications for business reinstate the need to invest in R\&D professional development and training programs, as that is a source of productivity and competitive advantage over sustained periods of time.

This study contributes to the empirical literature on R\&D investment with its comparative cross-country focus and drawing on recent data for Central and Eastern European economies. Three of the eleven countries studied in this paper, namely the Czech Republic, Hungary, and Poland, are present also in the sample of OECD economies used by Thomson (2017); however, to the best of our knowledge, there are no empirical studies with the same set of eleven economies. As the countries are comparable by the level of economic development and share a common history, we believe that the obtained results would be a valuable contribution to the extant literature on R\&D and fiscal policy. Future work should aim to obtain similar evidence on developing countries, e.g., in Asia, as comparative empirical evidence is currently lacking. Another line of research - perhaps more important in the light of the findings of the current paper - is to examine the impact of the relative prices of $R \& D$ inputs, including labour and equipment, on the variance of private $R \& D$ investment across countries. 


\section{Conclusion}

This study aimed to make a contribution to the empirical literature on fiscal policy and corporate R\&D investment by analysing Central and Eastern European data. In contrast to earlier evidence from OECD countries, the findings of this paper do not support the hypothesis that tax incentives and subsidies have a significant impact on business R\&D while controlling for other factors. The number of full-time equivalent researchers is found to have the most significant and the greatest impact on R\&D investment across countries. Tertiary education attainment and trade openness are also found to have a significant positive impact. As the models in this study were estimated with a random-effects regression with clustered robust standard errors, the findings from the sample of eleven countries over ten years can be generalised to other economies. Nevertheless, more research is needed on the impact of input costs on R\&D expenditure across countries, as well as on fiscal policy and R\&D investment in developing countries.

\section{Acknowledgements}

The author would like to thank the Manoogian Simone Research Fund for providing funding for this research. She is also grateful to the dean of the College of Business and Economics at the American University of Armenia, Dr Vache Gabrielyan, as well as two anonymous referees, for reviewing the drafts of this paper and providing feedback that has helped to improve it.

\section{References}

Aghion, P., \& Howitt, P. (1992). A Model of Growth Through Creative Destruction. Econometrica, 60(2), 323-351. https://doi.org/10.2307/2951599

Arrow, K. (1962). Economic welfare and the allocation of resources for invention. In R. Nelson (Ed.), The Rate and Direction of Inventive Activity: Economic and Social Factors (pp. 609-626). Princeton University Press.

Auerbach, A. J. (1979). Wealth Maximisation and the Cost of Capital. The Quarterly Journal of Economics, 93(3), 433-446.

Auerbach, A. J. (2018). Measuring the Effects of Corporate Tax Cuts. Journal of Economic Perspectives, 32(4), 97-120. https://doi.org/10.1257/jep.32.4.97

Becker, B. (2015). Public R\&D Policies and Private R\&D Investment: A Survey of the Empirical Evidence. Journal of Economic Surveys, 29(5), 917-942. https://doi.org/10.1111/joes.12074

Bloom, N., Griffith, R., \& Van Reenen, J. (2002). Do R\&D Tax Credits Work? Evidence from a Panel of Countries 1979-1997. Journal of Public Economics, 85(1), 1-31. https://doi.org/10.1016/S0047-2727(01)00086-X

Coe, D. T., \& Helpman, E. (1995). International R\&D Spillovers. European Economic Review, 39(5), 859-887. https://doi.org/10.1016/0014-2921(94)00100-E

Corrado, C., Hulten, C., \& Sichel, D. (2009). Intangible Capital and U.S. Economic Growth. Review of Income and Wealth, 55(3), 661-685. https://doi.org/10.1111/j.1475-4991.2009.00343.x

Cummins, J. G., Hassett, K. A., \& Hubbard, R. G. (1994). A Reconsideration of Investment Behavior Using Tax Reforms as Natural Experiments. Brookings Papers on Economic Activity, 1994(2), 1-74. https://doi.org/10.2307/2534654 
Dawson, J. W. (1998). Institutions, Investment, and Growth: New Cross-Country and Panel Data Evidence. Economic Inquiry, 36(4), 603-619. https://doi.org/10.1111/j.14657295.1998.tb01739.x

De Long, J. B., \& Summers, L. H. (1991). Equipment Investment and Economic Growth. The Quarterly Journal of Economics, 106(2), 445-502. https://doi.org/10.2307/2937944

Edquist, C. (Ed.). (1997). Systems of Innovation: Technologies, Institutions, and Organisations. Routledge.

European Commission. (2021). Eurostat Database. https://ec.europa.eu/eurostat/data/database

Falk, M. (2006). What Drives Business Research and Development (R\&D) Intensity across Organisation for Economic Co-operation and Development (OECD) Countries? Applied Economics, 38(5), 533-547. https://doi.org/10.1080/00036840500391187

Goolsbee, A. (1998). Does Government R\&D Policy Mainly Benefit Scientists and Engineers? The American Economic Review, 88(2), 298-302.

Griffith, R., Sandler, D., \& Van Reenen, J. (1995). Tax Incentives for R\&D. Fiscal Studies, 16(2), 2144.

Griliches, Z. (1992). The Search for R\&D Spillovers. The Scandinavian Journal of Economics, 94, S29S47. https://doi.org/10.2307/3440244

Griliches, Z. (1998). R\&D and Productivity: The Econometric Evidence. University of Chicago Press.

Grossman, G. M., \& Helpman, E. (1990). Comparative Advantage and Long-Run Growth. The American Economic Review, 80(4), 796-815.

Grossman, G. M., \& Helpman, E. (1991). Innovation and Growth in the Global Economy. MIT Press.

Grossman, G. M., \& Helpman, E. (1994). Endogenous Innovation in the Theory of Growth. Journal of Economic Perspectives, 8(1), 23-44. https://doi.org/10.1257/jep.8.1.23

Guellec, D., \& Van Pottelsberghe De La Potterie, B. (2003). The Impact of Public R\&D Expenditure on Business R\&D. Economics of Innovation and New Technology, 12(3), 225-243. https://doi.org/10.1080/10438590290004555

Hall, B. H. (2002). The Financing of Research and Development. Oxford Review of Economic Policy, 18(1), 35-51. https://doi.org/10.1093/oxrep/18.1.35

Hall, B. H., \& Lerner, J. (2010). The financing of R\&D and innovation. In B. H. Hall \& N. Rosenberg (Eds.), Handbook of the Economics of Innovation (Vol. 1, pp. 609-639). North-Holland. https://doi.org/10.1016/S0169-7218(10)01014-2

Hall, B., \& Van Reenen, J. (2000). How Effective are Fiscal Incentives for R\&D? A Review of the Evidence. Research Policy, 29(4), 449-469. https://doi.org/10.1016/S0048-7333(99)00085-2

Hall, R. E., \& Jones, C. I. (1999). Why do Some Countries Produce So Much More Output Per Worker than Others? The Quarterly Journal of Economics, 114(1), 83-116. https://doi.org/10.1162/003355399555954

Hall, R. E., \& Jorgenson, D. W. (1967). Tax Policy and Investment Behavior. The American Economic Review, 57(3), 391-414.

Hall, R. E., \& Jorgenson, D. W. (1969). Tax Policy and Investment Behavior: Reply and Further Results. The American Economic Review, 59(3), 388-401. 
Hassett, K. A., \& Hubbard, G. R. (2002). Tax policy and business investment. In A. J. Auerbach \& M. Feldstein (Eds.), Handbook of Public Economics (Vol. 3, pp. 1293-1343). Elsevier. https://doi.org/10.1016/S1573-4420(02)80024-6

International Monetary Fund. (2021). World Economic Outlook Database. https://www.imf.org/en/Publications/WEO/weo-database/2021/April

Jones, C. I., \& Williams, J. C. (1998). Measuring the Social Return to R\&D. The Quarterly Journal of Economics, 113(4), 1119-1135. https://doi.org/10.1162/003355398555856

Jones, C. I., \& Williams, J. C. (2000). Too Much of a Good Thing? The Economics of Investment in R\&D. Journal of Economic Growth, 5(1), 65-85. https://doi.org/10.1023/A:1009826304308

Jorgenson, D. W. (1963). Capital Theory and Investment Behavior. The American Economic Review, 53(2), 247-259.

King, M. A. (1974). Taxation and the Cost of Capital. Review of Economic Studies, 41(1), 21-35.

Klemm, A. (2010). Causes, Benefits, and Risks of Business Tax Incentives. International Tax and Public Finance, 17(3), 315-336. https://doi.org/10.1007/s10797-010-9135-y

Klemm, A., \& Van Parys, S. (2012). Empirical Evidence on the Effects of Tax Incentives. International Tax and Public Finance, 19(3), 393-423. https://doi.org/10.1007/s10797-011-9194-8

Leyden, D. P., \& Link, A. N. (1993). Tax Policies Affecting R\&D: An International Comparison. Technovation, 13(1), 17-25. https://doi.org/10.1016/0166-4972(93)90011-J

Lichtenberg, F. R., \& Siegel, D. (1991). The Impact of R\&D Investment on Productivity-New Evidence Using Linked R\&D-LRD Data. Economic Inquiry, 29(2), 203-229. https://doi.org/10.1111/j.1465-7295.1991.tb01267.x

Mankiw, N. G., Romer, D., \& Weil, D. N. (1992). A Contribution to the Empirics of Economic Growth. The Quarterly Journal of Economics, 107(2), 407-437. https://doi.org/10.2307/2118477

Mansfield, E. (1982). Tax Policy and Innovation. Science, 215(4538), 1365-1371. https://doi.org/10.1126/science.215.4538.1365

Mansfield, E. (1986). The R\&D Tax Credit and Other Technology Policy Issues. The American Economic Review, 76(2), 190-194.

Mokyr, J. (1992). The Lever of Riches: Technological Creativity and Economic Progress. Oxford University Press.

Organisation for Economic Co-operation and Development (OECD). (2021). Implied tax subsidy rates on R\&D expenditures. https://stats.oecd.org/Index.aspx?DataSetCode=RDSUB

Property Rights Alliance. (2020). International Property Rights Index. http://www.internationalpropertyrightsindex.org

Romer, P. M. (1986). Increasing Returns and Long-Run Growth. Journal of Political Economy, 94(5), 1002-1037.

Romer, P. M. (1990). Endogenous Technological Change. Journal of Political Economy, 98(5), S71S102.

Schumpeter, J. A. (1943). Capitalism, Socialism and Democracy. Routledge.

Shah, A. (Ed.). (1995). Fiscal Incentives for Investment and Innovation. Oxford University Press.

Thomson, R. (2017). The Effectiveness of R\&D Tax Credits. The Review of Economics and Statistics, 99(3), 544-549. https://doi.org/10.1162/REST_a_00559 
Van Parys, S., \& James, S. (2010). The Effectiveness of Tax Incentives in Attracting Investment: Panel Data Evidence from the CFA Franc Zone. International Tax and Public Finance, 17(4), 400429. https://doi.org/10.1007/s10797-010-9140-1

Varsakelis, N. C. (2001). The Impact of Patent Protection, Economy Openness and National Culture on R\&D Investment: A Cross-country Empirical Investigation. Research Policy, 30(7), 10591068. https://doi.org/10.1016/S0048-7333(00)00130-X

Wang, E. C. (2010). Determinants of R\&D Investment: The Extreme-Bounds-Analysis Approach Applied to 26 OECD Countries. Research Policy, 39(1), 103-116. https://doi.org/10.1016/j.respol.2009.11.010

Wolff, G. B., \& Reinthaler, V. (2008). The Effectiveness of Subsidies Revisited: Accounting for Wage and Employment Effects in Business R\&D. Research Policy, 37(8), 1403-1412. https://doi.org/10.1016/j.respol.2008.04.023

Wooldridge, J. M. (2010). Econometric Analysis of Cross Section and Panel Data (2nd ed.). MIT Press.

World Bank. (2020). Worldwide Governance Indicators. https://info.worldbank.org/governance/wgi/

World Bank. (2021). DataBank: World Development Indicators. https://databank.worldbank.org/source/world-development-indicators

The research paper passed the review process. | Received: August 17, 2021; Revised: September 29, 2021; Accepted: October 15, 2021; Pre-published online: January 18, 2022; Published in the regular issue: July 18, 2022. 


\section{Appendix}

Table A1 | Fixed-effects regression results

\begin{tabular}{|c|c|c|c|c|c|c|}
\hline & (1) & (2) & (3) & (4) & (5) & (6) \\
\hline \multirow[t]{2}{*}{ TTCR } & 0.00 & & & 0.00 & 0.00 & -0.01 \\
\hline & $(0.01)$ & & & $(0.01)$ & $(0.01)$ & $(0.01)$ \\
\hline \multirow[t]{2}{*}{ GBAORD } & & 0.17 & & 0.13 & $0.19^{*}$ & $0.17^{\star}$ \\
\hline & & $(0.21)$ & & $(0.14)$ & $(0.11)$ & $(0.08)$ \\
\hline \multirow[t]{2}{*}{ ITSR } & & & 0.48 & 0.48 & 0.00 & 0.01 \\
\hline & & & $(0.35)$ & $(0.35)$ & $(0.16)$ & $(0.17)$ \\
\hline \multirow[t]{2}{*}{$L T I R$} & & & & & 0.03 & $0.03^{*}$ \\
\hline & & & & & $(0.02)$ & $(0.02)$ \\
\hline \multirow[t]{2}{*}{ Log FTR } & & & & & $0.23^{\star * *}$ & $0.21^{\star \star \star}$ \\
\hline & & & & & $(0.06)$ & $(0.05)$ \\
\hline \multirow[t]{2}{*}{$T E$} & & & & & $0.03^{\star *}$ & 0.02 \\
\hline & & & & & $(0.01)$ & $(0.01)$ \\
\hline \multirow[t]{2}{*}{ GOV } & & & & & $-0.63^{* *}$ & $-0.61^{\star *}$ \\
\hline & & & & & $(0.28)$ & $(0.23)$ \\
\hline \multirow[t]{2}{*}{$I P R$} & & & & & -0.01 & -0.02 \\
\hline & & & & & $(0.04)$ & $(0.07)$ \\
\hline \multirow[t]{2}{*}{ TRADE } & & & & & & 0.00 \\
\hline & & & & & & $(0.00)$ \\
\hline \multirow[t]{2}{*}{ GRGDP } & & & & & & 0.00 \\
\hline & & & & & & $(0.01)$ \\
\hline \multirow[t]{2}{*}{ Log GDPPC } & & & & & & 0.13 \\
\hline & & & & & & $(0.18)$ \\
\hline \multirow[t]{2}{*}{ Constant } & 0.43 & $0.45^{\star *}$ & $0.57^{\star \star *}$ & 0.30 & $-1.77^{\star \star \star}$ & $-3.05^{\star}$ \\
\hline & $(0.53)$ & $(0.21)$ & $(0.04)$ & $(0.56)$ & $(0.59)$ & $(1.42)$ \\
\hline$\sigma u$ & 0.44 & 0.42 & 0.43 & 0.42 & 0.47 & 0.41 \\
\hline & 0.14 & 0.42 & 0.13 & 0.42 & 0.47 & 0.41 \\
\hline$\rho$ (fraction of & 0.89 & 0.88 & 0.89 & 0.88 & 0.95 & 0.93 \\
\hline $\begin{array}{l}\text { variance due to } \\
\text { u i) }\end{array}$ & & & & & & \\
\hline \multirow{3}{*}{$\begin{array}{r}\text { within } \\
\text { between } \\
\text { overall }\end{array}$} & 0.01 & 0.02 & 0.05 & 0.08 & 0.51 & 0.52 \\
\hline & 0.00 & 0.11 & 0.06 & 0.15 & 0.03 & 0.15 \\
\hline & 0.00 & 0.10 & 0.05 & 0.13 & 0.06 & 0.19 \\
\hline Observations & 110 & 110 & 110 & 110 & 110 & 110 \\
\hline Groups & 11 & 11 & 11 & 11 & 11 & 11 \\
\hline
\end{tabular}

Source: author 